\title{
Historein
}

Vol 13 (2013)

Questions and Orientations in History during the last 20 years. Part 2

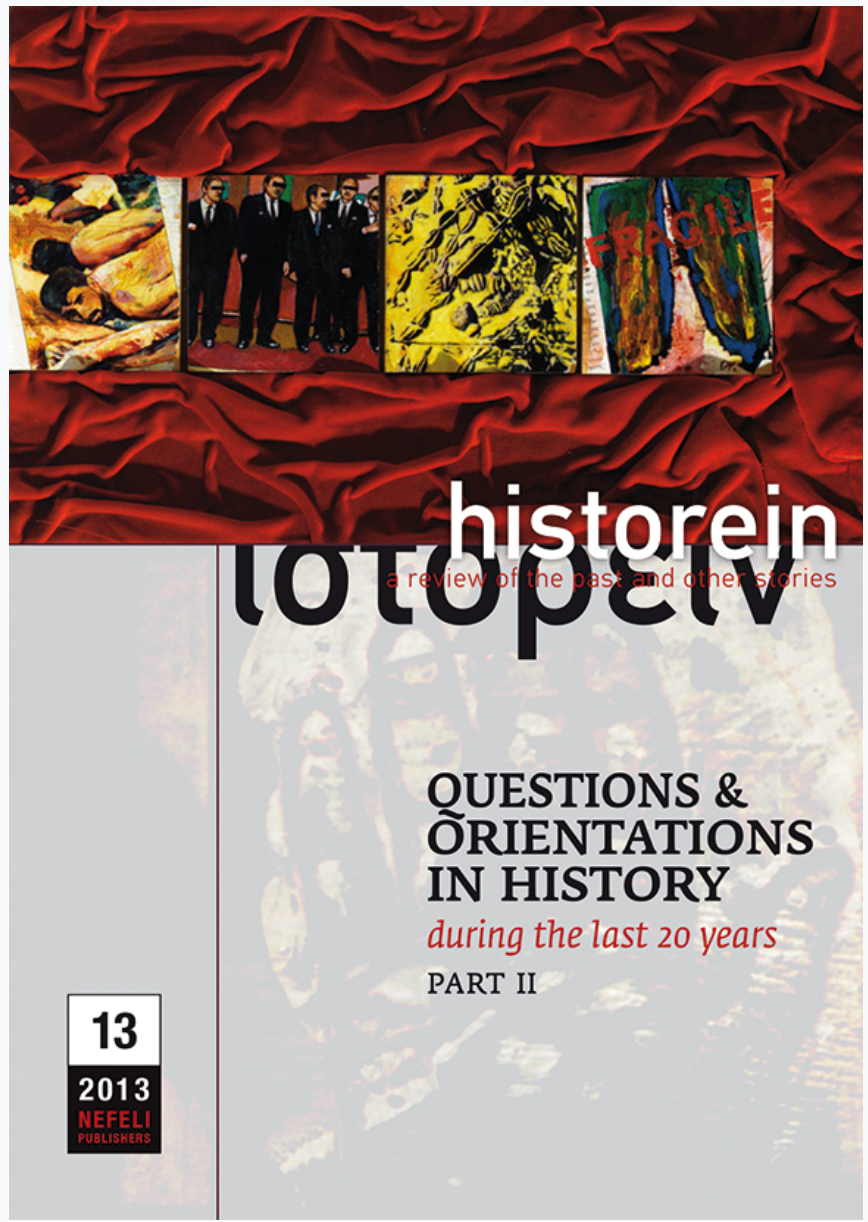

Global history in the age of crisis: metanarratives of material progress and the rise of Asia

Sakis Gekas

doi: $10.12681 /$ historein.163

Copyright @ 2014, Sakis Gekas

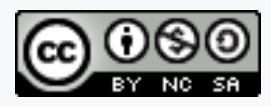

This work is licensed under a Creative Commons Attribution-NonCommercialShareAlike 4.0.

To cite this article:

Gekas, S. (2013). Global history in the age of crisis: metanarratives of material progress and the rise of Asia. Historein, 13, 8-17. https://doi.org/10.12681/historein.163 


\section{Global history in}

\section{the age of crisis:}

metanarratives of

material progress

\author{
and the rise of Asia
}

We cannot foresee the solutions of the problems facing the world in the twenty-first century, but if they are to have a chance of success they must ask Marx's questions, even if they do not wish to accept his various disciples' answers.'

Twenty years after the term "global history" was coined for the first time at a congress in Bellagio, Italy, the Historein workshop on historiographical and theoretical challenges of the last two decades, held in Athens in December 2012, was a most appropriate forum to reflect on the field of global history. At the Bellagio congress, William McNeill acknowledged that a new trend was emerging although he did not differentiate it from world history. ${ }^{2}$ Following the heyday of globalisation in the 1990s, global history flourished in a handful of UK, US and European historical research centres. This new approach talked about global connections, comparisons and the history of globalisation, continuing the older historiographical tradition of world history that emerged in the 1960s and entered a new trajectory in the 1990s and 2000s under the title global and - as it has been recently called in some quarters - transnational history, with differences in approach as well as scope. ${ }^{3}$

Global history fertilised a range of fields from human rights to migration, gender, technology, to the history of globalisation and its diffusion around the world, ${ }^{4}$ but also the history of revolutions, an older field that continues to fascinate, and the diffusion of liberalism, part of an emerging "global intellectual history". ${ }^{5}$ Lefteris Stavrianos, a prominent member of the Chicago historians in the 1960s, together with McNeill, and Fernand Braudel have influenced environmental history. ${ }^{6}$ Jared Diamond and David Christian, 
even more ambitiously, integrate the first human migrations out of Africa, natural and human history and the big bang, into a single and grand narrative. ${ }^{7}$ These are works of truly global or universal history, certainly interdisciplinary in scope and definitely big, as Christian prefers to call it. ${ }^{8}$ Recently, studies that take a global and transnational approach to the history of class have appeared, interestingly of the middle, the only class that liberal politicians seem comfortable talking about these days. ${ }^{9}$ Other new fields include also the history of material culture of global connections, comparisons in technology and the history of commodities, from the late medieval and early modern periods, as well as the history of consumption and its importance for demand-side economic development. ${ }^{10}$ It is the question of economic divergence, however, that has been most prominent in global history debates, and the issue of why the "west" got so rich in the modern period and the "rest" are only recently catching up.

In recent decades, many historians abandoned grand or "metanarratives", especially Marxist interpretations of history, for the sake of cultural and "microhistory" approaches or no narratives at all. The myth of European supremacy and progress was rejected and incredulity towards metanarratives and their reliance on transcendent and universal truth defined the postmodern. ${ }^{11}$ Grand narratives continue, however, to haunt historians and dominate the historical canon: industrialisation, the rise and fall of empires, the formation of the working class, the emancipation of women, the creation of (European) nation-states and colonial expansion and imperialism. Scholars have criticised Eurocentric historiography, especially under the influence of postcolonial studies; European colonialists managed to colonise history as well as other peoples' lands and bodies. ${ }^{12}$ This colonisation occupied a historical and cultural space with selective narratives that buttress an older Eurocentric metanarrative of superiority. Well-received by historians, this critique has reinvigorated the history of empires, in ancient as well as modern times, again from a global perspective. ${ }^{13}$ The grand concepts, "progress", "capital" and the "state" proved, we were told, inadequate to explain the historical trajectory of people around the globe, targeting and questioning the purpose of history itself and provincialising a declining Europe. ${ }^{14}$

This correction and revision should not come as a surprise; Europe constructed factories, financed wars and empires, dominated continents but, most importantly, reinvented history itself. The Eurocentric and exceptionally enduring tradition of metanarratives of material progress goes back to Marx and Weber..$^{15}$ The tools, theories and concepts of global economic history owe a lot to these two scholars. Both Marx and Weber wrote with alacrity and acute interest about the economies of India, China, Africa and Russia. Marx focused on "the modes of production", what many economists and historians especially in the US call property rights. Marx's Eurocentrism transpires through the idea that European industrial machines would eventually bring social progress and would help regenerate Asian societies, part of his well-known admiration of capitalism for the unprecedented productive forces it unleashed. ${ }^{16}$ Weber's theoretical contribution, on the other hand, was based on the relationship between religion and the development of capitalism, according to which systems of faith became the driving force of human history. Weber, together with the German histori- 
cal school, also stressed the importance of institutions long before economic historians in the US discovered their explanatory power and received Nobel prizes. ${ }^{17}$

Beyond institutions and merely economic and quantitative methods, two approaches distinguish many recent works in global economic history that seek to integrate economic and cultural history: connections and comparisons. Drawing on the seminal contributions of McNeill, who established "connections", "interactions", "encounters" and "contacts" with peoples, historians look for economic, social, political, military, cultural, religious, technological and environmental change in what could be described as a "global" or "transnational" turn. The history of migration, disease, the "Columbian exchange" and (more recently) the transfer of useful and reliable knowledge are some of the fields that connect continents, peoples and cultures in books that have become ever more popular. Historians - often polemic - focus also on other connections: exploitation, slavery and war. One generation on from McNeill's connections and interactions approach, the history of comparisons, pioneered by Marc Bloch, acquired a new status after Kenneth Pomeranz's comparisons of eighteenth-century England and China, or "Europe" and "Asia", led him to coin the term "great divergence".

The challenge to unquantified but not unquantifiable claims that European economies were on a trajectory to modern economic growth for centuries before industrialisation is but two generations old; since Braudel's time in the 1970s to Pomeranz's in 2000, historians showed how similar living standards and preconditions for growth were present in both Asia and Europe until 1800. The difference was not quantitative but qualitative; Europe invented historians and narratives of superiority that projected technological progress and economic growth further back in time than it deserved or than is currently thought (as in the work of David Landes). More than ten years after his interpretation of the great divergence, Pomeranz's argument has entered the historical canon but the questions why England did not continue to fare like the Yangzi delta, and followed the trajectory to industrialisation instead, remain. A recent book contends that the British developed an independent and exceptional road to growth and wealth through trade, quantifying the achievement through comparison with other "candidates" for industrialisation. ${ }^{18}$ Others see the industrial economy as a product of the Enlightenment and the rise to prominence of bourgeois society and ideas. The keyword here is innovation, in words that were convincing ("rhetoric") as well as in deeds that were put into industrial production first in seventeenth-century Netherlands and, later on, in Britain and, since then, in the rest of the world. Such a platform promises almost evangelically to rid all societies from poverty once they adopt bourgeois rhetoric and values; just as the Dutch and the English supposedly did in the past. ${ }^{19}$ Despite this recent Enlightenment turn by several economic historians approaching the end of their career, Weber has been more influential in works that praise the "European miracle", ${ }^{20}$ and in global histories of material progress. Weber acknowledged, after all, the exceptional Indian and Chinese contributions to technological and institutional innovation in domestic and international trade. Weber taught us that there were stark differences between political institutions and the intellectual trajectories that set Asia on a different - not a superior or inferior - course from Europe and led to the great divergence; this started, for some historians, in 1000-1200 CE (Common Era), for others in 1500 and for a third group around 1800. ${ }^{21}$ Adam Smith, however, is really to "blame" for establishing one of the founding metanarratives of world history. Smith considered the "discovery" of America and the circumnavigation of Africa as the most im- 
portant development of human history and established the metanarrative of European economic expansion. ${ }^{22}$ Since then, the metaquestion of why Europeans moved into the era of sustained growth first has dominated economic and other historians in global history.

Innovation, Enlightenment and "bourgeois values" represent a return to Eurocentrism by scholars interested in the "wealth and poverty" of societies. The triumphalist literature of the English industrial revolution and the cotton industry in the nineteenth century distorted our view of productive capabilities and living standards elsewhere in the world. Global history corrects old meta-narratives of material progress. The long-overdue response to this literature advanced the debate on the great divergence from the comparison between England and China to the comparison between India and England and, to a lesser extent, between the Ottoman Empire and France. ${ }^{23}$ This work places the importance of coal, colonies and technological breakthroughs - undoubtedly important for British industrialisation - into a global framework by comparing and connecting different parts of the world, and shows the drive of British and other European producers to outperform India and its unsurpassed quality in cotton textile production. As a result, there was no divergence until the end of the eighteenth century - rather late by standards of an older historiography - while the state in India, unlike in Britain, was absent in providing support for cotton manufacturing. Unlike a previous literature that argued for a collapse of state structures in south Asia that paved the way for colonisation, the state was central to industrialisation, innovation and in creating divergence and colonial expansion.

Marx also posed the issue why this transition first took place in western Europe and not in other parts of the world; this question concerned disciples of the world systems school of historical sociology, a field where global history found fertile ground even if mostly from a Eurocentric point of view. Their basic premise is that for three centuries, Europeans, and not Chinese, Indians or Africans, accumulated profits from intercontinental trade, together with the exploitation and the appropriation of raw materials, gold and silver, timber but especially slavery that Europeans imposed. Profits from goods, raw materials and ideas, plants and herbs arrived at European ports, first those in the Iberian peninsula, later in Holland and then France and Britain, the latter being the biggest free rider in the history of material progress.

The historical discontinuity of European expansion to America and later to Asia coincided with the expansion of violence and conflict within Europe. Global history has returned to grand narratives, armed with the collection and evaluation of historical information generated by local, regional, national or transnational historiographies, and aspires to a unified and hopefully convincing history, not a history based on transcendent or universal truths. A metanarrative does not need to identify with the history of a whole continent, let alone the planet, over a period of 500 years but aspires to put some order into the overload of information about the past. Recently, histories that take one thread and spin it around the world, such as the history of commodities or the history of ideas and movements, are likely to become popular especially as the history of globalisation is taught in many history departments, substituting the older "history of western civilisation(s)". ${ }^{24}$ In this sense, a metanarrative does not "claim to discover" a past, this being the "duty" and aim of a more traditional narrative, but to reorder and reclassify historical knowledge with fresh questions, approaches and methodologies and with the aim of better understanding an otherwise fragmented past. 
Whole empires are now placed under the rubric of global history, which has generated new interest and "discovered" new fields; the Ottoman Empire, traditionally compared with other "gunpowder empires", is now commonly compared with early modern European empires but within a global framework. ${ }^{25}$ These novel approaches improve our understanding of the role of the Ottomans in the age of exploration and in the so-called "periphery", such as the Indian Ocean, also now at the "core" of the global historians' agenda. ${ }^{26}$ The assumption that the whole of northwestern Europe was the centre of the globalising economy from the 1500 s and was "destined" to move to sustained growth has been severely challenged if not outright rejected. The Ottoman Empire was the centre of the Ottoman economy, China the centre of the Chinese economy, and the most dynamic regions of south Asia the centre of the Indian Ocean economy. The survival of a vast collection of European sources about European chartered companies and trade has attracted incomparably more attention to the trade between the Ottoman Empire and south Asia, which according to one estimate was about five times greater than the trade of Europeans with south Asia. Until this gap in our knowledge is filled (providing this is possible), it will be difficult to establish the interconnection and economic networks of the Indian Ocean and the Ottoman Empire. A clear research agenda with a significant empirical base presents the opportunity to write a polycentric global economic history in our polycentric times that corrects the myth of European supremacy before 1800 . Such a trend is unlikely to subside any time soon, especially in these times of global crisis. Even if many historians from the "east" and the "global south" still train in North American and British universities, they already work on the hypothesis that Asia (and by implication other parts of the world) was following its own trajectory to development, a historical potential that was irrevocably annulled by colonialism and subsequent world wars.

The past is always revisited through the lens of the present. The decline of the American superpower, the end of the "American century" and the rise of Asia was predicted in the 1990s, followed by arguments about the "Eastern origins of Western civilisation". ${ }^{27}$ In the 1990s, the rise of Asia was attributed (and still is by many) to "capitalism with Asian values", an odd and conservative neo-Weberian perception of economic and social development that masks and legitimises neoliberal and authoritarian capitalism with a communist face. China continues to puzzle, as an unprecedented phenomenon of an efficient capitalism without democracy, and emerges as the other systemic alternative to the morally bankrupt neoliberalism of western economies. The political exception of some Latin American countries remains outside the systemically "acceptable" forms of capitalism, although these forms might turn out to be far more productive and mainstream than is now assumed. On the contrary, a democratic deficit has grown proportionally to the increasing depth and length of capitalist crises, from the 1970 s to the early 1990 s to the current one. Western capitalist societies - formerly considered immune - have entered a downward spiral of crisis from which they find very hard to pull back, as the accumulation of wealth coupled with growing inequality accelerates in Eurasia, North America and in the rising economic powers of Brazil, Russia, India and China (Brics). Transnational crises with global implications, such as the current one, require by definition readings that transcend national borders but also stress how local and national conditions may determine how these crises will evolve. Against this sombre global outlook, the approach, thinking and writing of global history can draw on the rise in inequality around the globe (in the US among other places) and offer a new narrative of economic crises and global politics; what follows provides a glimpse into such approaches. 
The sovereign debt crisis is provoking histories of debt, conceptualising it as a complex act of unequal reciprocity and a gift relationship. ${ }^{28}$ Economic historians and more lay commentators often evoke the depression of the 1870 s and especially the Great Depression of the 1930s to understand, explain or warn about the consequences of the current crisis. Historians of British imperialism have shown how colonial expansion during the last quarter of the nineteenth century coincided with the galloping development of industrial capitalism in western Europe, North America and Japan, which financed the City of London as it gradually became the centre of the gold standard universe. ${ }^{29}$ The gold standard regime advanced British imperialist expansion but also the stability of European and some peripheral economies from 1880 to 1914 . The gold standard was not only a system to which many countries subscribed because it secured much-needed funds for industrialisation (Greece entered the financial markets during that period for exactly this purpose); the gold standard came attached with colonial or semicolonial strings that controlled banking systems in return for participation in the gold standard. The first so-called modern crisis of the 1870 s accelerated British imperialist expansion through the adoption of the gold standard; it also advanced the accumulation of capital to such an extent that it forced its expansion into many parts of the world, unsettling equilibriums and geopolitics in the whole "periphery" ${ }^{30}$ Industrialisation and westbound railway expansion in North America, the rapid growth of the Argentine economy, the hegemony of European (French and British) capital in the Ottoman Empire and especially Egypt, the opium wars in China and the unravelling of the productive base in India are only some expressions of the almost simultaneous British imperial and financial expansion.

The depression of the 1930s has generated such a rich historiography that it would be futile to even try to summarise it here; famous policymakers include students of the 1929 crash and 1930s depression policies (the current chairman of the US Federal Reserve). Future historians will reflect similarly, if not to a greater extent, on the present crisis, already considered a "game changer" because of its depth, length and political ramifications for the future of the European Union. This crisis, when related to the rise of Asian economies, has intensified existing anxieties in the "west" about the decline of "Europe" and the US, especially its inability to maintain its hegemony abroad but also the standard of living of its middle class at home. ${ }^{31}$ There is little doubt that the productive, but also the consuming, base of the global economy is increasingly shifting to Asia, which for some longue durée historians is a "correction" of the aberration of the last 300 years. This shift only partly explains the anxieties of historians and economists about the rise of Asia or rather the "failure" of the west. Fiscal exhaustion in the US following the wars in Iraq and Afghanistan raised the alarm; the socialisation of losses in the financial sector since September 2008 and the continuing transfer of these losses to national budgets, first in the USA and then in Europe produced social crises and continues to upset world leaders, not just those of the EU but also of the G8 (increasingly meeting as the $\mathrm{G} 20$ ).

This is a new literature emerging that struggles to see through the fog and explain how the crisis will affect societies in the future from a global perspective. However, in the post-1945 decades of affluence, studies on the history of crises, the work of Charles Kindleberger being the only exception, were few and far between. ${ }^{32}$ His interpretation of the interwar depression as a crisis that worsened as a result of the indolence of the declining power, Britain, and the unwillingness of the rising power, the US, to show leadership resonates today with analysts who draw parallels with the 
role of Germany in the eurozone. A second, more recent work is a quantitative history of financial crises that pays little attention to historical perception and depth, however. ${ }^{33}$ Using a mountain of data sampled from 66 countries and over eight centuries, primarily after the 1850s when national accounts became more reliable, the authors take an evolutionary approach to history with no consideration for the problematic creation of statistics and the even more dubious use of national accounts to compare the present with the past. ${ }^{34}$ The authors believe countries "graduate" from debt crises, although no country remains immune to them. Emerging economies today will mature (at some indeterminate point in the future), and like today's strong economies they will become more stable and able to avoid defaulting on their financial obligations to creditors. The authors provide the "missing link" in explanations of the crisis - the domestic debt that governments historically and even today arduously avoid publishing. Still, according to this evolutionary model of "graduation" from defaulting, no country, we are told, has graduated from banking crises, as the collapse of Northern Rock and Lehman Brothers demonstrated and the Spanish banks prove. Banking and financial crises however are inherent in advanced financial capitalism while the interconnectedness of the global financial system creates more crises, especially after the deregulation of the financial markets. The model proposed by Reinhart and Rogoff is not just evolutionary, it is financial Darwinism: only the fittest will survive.

In 2007, however, the world as we knew it in the "west" began to crumble; a housing bubble burst in the US, the financial sector nearly went into meltdown in September 2008, and a full-blown sovereign debt, banking and economic crisis erupted in Greece and elsewhere in the European periphery towards the end of 2009 and into 2010 . Since then, extreme austerity policies have dismantled welfare states and societies are unravelling; the ongoing crisis has unleashed politically promising forces on the left as well as violently anti-immigrant or simply "antipolitician" formations, which have tapped some of the frustration, anger and despair that has engulfed the new poor. However, the "west" is not collapsing rapidly nor have (parts of) Asia become in just a few years the wealthiest part of the world, even with the accumulation of surpluses and trillions of US dollar reserves by China. The dollar hegemony and the oil economy, and especially the high levels of management expertise, mean that the centre of the financial sector remains unequivocally in the "west", as no one else is ready to take the helm of the global capitalist system. ${ }^{35}$

This literature is clearly the result of the crisis, which has generated questions not only about economic but also political global governance as the two are no longer distinguishable (if they ever were). The "era of confusion" ended after an almost 200-year-old period of plans on how to govern the world. ${ }^{36}$ Practitioners of global history in the not-so-distant future will probably draw inspiration from the great divergence of our time while debates about the end of "western rule" will continue $;{ }^{37}$ the rapid expansion of inequalities in all parts of the world - east, west, the rich global north and the "developing" global south - is occuring simultaneously with the unravelling of the welfare state (where it exists) and the accumulation of wealth by oligarchies (in the rest of the world). This other great divergence - the growing of income inequalities in recent decades at a global scale - will probably become even more central for global histories of material progress as these inequalities widen. The relentless demand for raw materials in China and India and the production of industrial and other consumption goods has been moving from Europe to Asia for decades now, just as it moved from Asia to Europe in the eighteenth century. The chartered companies of the 
time played perhaps the most significant role in the domination of European capitalism worldwide. In the nineteenth and early twentieth centuries, old and aspiring empires of the "west" were prepared to go to great lengths to protect their countries' commercial and financial interests. Today governments, unwilling and unable to restrain and regulate the gigantic growth of the banking and financial sector and, even after the collapse of September 2008, are upholding the supremacy of global financial institutions and markets. The politics of austerity that governments are imposing under tremendous pressure from financial institutions and dubious credit-rating agencies serve to deepen and prolong the crisis and extend impoverishment while the public sector shrinks and the welfare state crumbles. It is not, however, the task of a review article to reflect on the political and historiographical consequences of this other great divergence of inequalities; perhaps this can be done on the next anniversary of Historein.

\section{NOTES}

* I would like to thank the organisers of the Historein workshop, where an earlier version of the article was presented, and especially the two anonymous reviewers for their constructive comments.

1 Eric Hobsbawm, How to Change the World: Reflections on Marx and Marxism, New Haven \& London: Yale University Press, 2011, 15.

2 Bruce Mazlish, "Comparing global history to world history", Journal of Interdisciplinary History 28/3 (1998), 385-395.

3 These however are not interchangeable terms. Transnational history is not necessarily global, it can be only European, American or Asian. Deborah Cohen, Maura O'Connor, "Comparative history, cross-national history, transnational history-definitions", in Deborah Cohen, Maura O'Connor (eds), Comparison and History: Europe in Cross-National Perspective, New York: Routledge, 2004, vii-xxiv. I thank one of the reviewers for the clarification. For a historiographical review, please see, Athanasios Gekas, "Aпó tnv

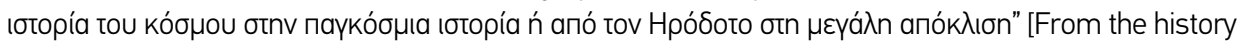
of the world to global history or from Herodotus to the great divergence], Mnemon 29 (2008), 243-273.

$4 \quad$ Bruce Mazlish and Akira Iriye (eds), The Global History Reader, New York \& London: Routledge, 2005; A.G. Hopkins (ed.), Globalization in World History, London: Pimlico, 2002.

5 David Armitage and Sunjay Subrahmanian, The Age of Revolutions in a Global Context, 1760-1840, London: Palgrave, 2009; Wim Klooster, Revolutions in the Atlantic World: A Comparative History, New York \& London: New York University Press, 2009; C.A. Bayly, Recovering Liberties: Indian Thought in the Age of Liberalism and Empire, Cambridge: Cambridge University Press, 2012.

6 Leften Stavros Stavrianos, A Global History of Man, Boston: Allyn \& Bacon, 1966.

7 William H. McNeill, The Rise of the West: A History of the Human Community, Chicago: Chicago University Press, 1963; William H. McNeill, The Pursuit of Power: Technology, Armed Forces and Society Since 1000 $A D$, Chicago: Chicago University Press, 1983; William H. McNeill, "The rise of the west after twenty-five years", Journal of World History 1/1 (1990), 1-21.

8 Jared Diamond, Guns, Germs, and Steel: A Short History of Everybody for the last 13,000 Years, New York, W.W. Norton, 1997; David Landes, The Wealth and Poverty of Nations: Why Some are So Rich and Some So Poor, New York: W.W. Norton 1998; David Christian, Maps of Time: An Introduction to Big History, Berkeley: University of California Press, 2004; Fred Spier, Big History and the Future of Humanity, 
Wiley-Blackwell, 2011.

9 A. Ricardo Lopez and Barbara Weinstein (eds), The Making of the Middle Class: Toward a Transnational History, Durham and London: Duke University Press, 2012.

10 Maxine Berg, “From global history to globalization”, History Workshop Journal 66 (2008), 335-340; Maxine Berg, Luxury and Pleasure in Eighteenth-Century Britain, Oxford: Oxford University Press, 2005; Giorgio Riello, "Asian knowledge and the development of calico printing in Europe in the seventeenth and eighteenth century", Journal of Global History 5 (2010), 1-28; Maxine Berg, "Useful knowledge, "industrial enlightenment', and the place of India”, Journal of Global History 8/1 (2013), 117-141.

11 Jean-François Lyotard, The Postmodern Condition: A Report on Knowledge, Minneapolis : University of Minnesota Press, 1984.

12 James M. Blaut, The Colonizer's Model of the World: Geographical Diffusionism and Eurocentric History, New York, Guilford, 1993, and James M. Blaut, Eight Eurocentric Historians, NY: Guilford Press 2000; Jack Goody, The Theft of History, Cambridge: Cambridge University Press, 2006; Frederick Cooper, Colonialism in Question: Theory, Knowledge, History, Berkeley: University of California Press 2005.

13 Jane Burbank and Frederick Cooper, Empires in World History: Power and the Politics of Difference, Princeton: Princeton University Press, 2010.

14 Dipesh Chakrabarty, Provincializing Europe: Postcolonial Thought and Historical Difference, Princeton: Princeton University Press, 2000.

15 These narratives also include Oswald Spengler and Arnold Toynbee, the former being perhaps among the first who talked about the "decline" of the west.

16 Michael Adas, Machines as the Measure of Men: Science, Technology, and Ideologies of Western Dominance, Cornell University Press 1989.

17 The classic works of Douglas North are typical of westerncentric approaches to an older economic history. More updated and focused on development and institutions are the works of Daron Acemoglu and James A. Robinson, Why Nations Fail: The Origins of Power, Prosperity and Poverty, New York: Crown Business, 2012.

18 Robert C. Allen, The British Industrial Revolution in Global Perspective, Cambridge: Cambridge University Press, 2009.

19 Deirdre McCloskey, Bourgeois Dignity: Why Economics can't explain the Modern World, Chicago: Chicago University Press 2011; Joel Mokyr, The Enlightened Economy: An Economic History of Britain, New Haven, 2009.

20 E.L. Jones, Growth Recurring: Economic Change in World History, Oxford: Oxford University Press, 1988.

21 Kenneth Pomeranz, The Great Divergence: China, Europe and the Making of the Modern World Economy, Princeton: Princeton University Press, 2000.

22 A wonderful demonstration of the discursive inversion that is appropriate every time the issue of European expansion is debated can be found in the Museum of Civilisation in Ottawa, where a caption under an exhibit mentions that the populations of the east coast of North America discovered European settlers for the first time in the sixteenth century.

23 Prasannan Parthasarathi, Why Europe grew rich and Asia did not: Global Economic Divergence, 16001850, Cambridge: Cambridge University Press, 2011.

24 Giorgio Riello and Prasannan Parthasarathi (eds), The Spinning World: A Global History of Cotton Tex- 
tiles, 1200-1850, Oxford \& New York: Oxford University Press, 2009.

25 Karen Barkey, Empire of Difference: The Ottomans in Comparative Perspective, Cambridge: Cambridge University Press, 2008; Baki Tezan, The Second Ottoman Empire: Political and Social Transformation in the Early Modern Age, Cambridge: Cambridge University Press, 2010.

26 Giancarlo Casale, The Ottoman Age of Exploration, Oxford: Oxford University Press, 2010.

27 Giovanni Arrighi, The Long Twentieth Century: Money, Power and the Origins of Our Times, London: Verso 1994; Andre Gunder Frank's classic ReOrient: Global Economy in the Asian Age, Berkeley: University of California Press, 1998; John M. Hobson, The Eastern Origins of Western Civilisation, Cambridge: Cambridge University Press, 2004.

28 David Graeber, Debt: The First 5000 years, New York: Melville House, 2011.

29 A.G. Hopkins and P. Cain, British Imperialism, 1688-2001, Harlow: Longman, 2001; A.G. Hopkins (ed.), Global History: Interactions between the Universal and the Local, London: Palgrave Macmillan, 2006.

30 G. Balachandran, "Power and markets in global finance: the gold standard, 1890-1926", Journal of Global History 3/3 (2008), 313-335.

31 Niall Ferguson, Civilization: The West and the Rest, London: Penguin, 2011; Niall Ferguson, Colossus: The Rise and Fall of the American Empire, London: Penguin, 2005. For more popularised books, see: Thomas L. Friedman and Michael Mandelbaum, That Used to be US: How America Fell Behind in the World in Invented and How We Can Come Back, New York: Farrar, Straus and Giroux, 2011.

32 Charles P. Kindleberger, Manias, Panics and Crashes: A History of Financial Crises, New York: Basic Books, 1978 (now in its sixth edition); Charles P. Kindleberger, The 1930s and the 1980s: Parallels and Differences, Singapore: Asean Economic Research Unit, Institute of Southeast Asian Studies, 1989.

33 Carmen M. Reinhart and Kenneth S. Rogoff, This Time Is Different: Eight Centuries of Financial Folly, Princeton \& Oxford: Princeton University Press, 2009.

34 Morten Jerven, "An unlevel playing field: national income estimates and reciprocal comparison in global economic history", Journal of Global History 7/1 (2012), 107-128.

35 Leo Panitch and Sam Gindin, The Making of Global Capitalism: The Political Economy of American Empire, London \& New York, 2012; Yanis Varoufakis, The Global Minotaur: America, the True Origins of the Financial Crisis and the Future of the World Economy, London \& New York, Zed Books, 2011.

36 Mark Mazower, Governing the World: The History of an Idea, New York, Penguin, 2012.

37 Ian Morris, Why the West rules - for Now: The Patterns of History and What they Reveal about the Future, London: Profile Books, 2010. 